\title{
ANALISIS VIABILITAS LACTOBACILLUS LACTIS PADA INOVASI MEDIA DASAR PERTUMBUHAN ALTERNATIF DAN MEDIA DASAR PENEPUNGAN BAKTERI ASAM LAKTAT
}

\author{
Ani Sulastri ${ }^{1^{\star}}$, Baso Manguntungi ${ }^{2}$, Leggina Rezzy Vanggy ${ }^{3}$ \\ ${ }^{1 *}$ Program Studi Manajemen Inovasi, Program Magister Universitas Teknologi Sumbawa \\ ${ }^{2}$ Program Studi Teknobiologi, Fakultas teknobiologi, Universitas Teknologi Sumbawa \\ ${ }^{*}$ Corresponding Author email: ${ }^{1}$ ani.sulastri@uts.ac.id, ${ }^{2}$ baso.manguntungi@uts.ac.id
}

\section{Diterima \\ Bulan Juni 2020}

\section{Diterbitkan}

Bulan Juli 2020

Keyword : Lctobacillus lactis, Bakteri asam laktat, Viabilitas, Whey tahu

\section{Abstrak}

Terbatasnya waktu masa simpan dalam suatu bahan pangan dibutuhkan suatu bahan pengawet alami agar bahan pangan yang digunakan tersebut tidak mudah mengalami kerusakan dan memiliki masa simpan yang lebih lama yakni dengan menggunakan bakteri asalam laktat (BAL) menggunakan media alternative.Dengan menggunakan bakteri asam laktat maka waktu dalam masa penyimpanan produk pangan dapat diperpanjang. Tujuan dari penelitian ini adalah untuk mengetahui viabilitas bakteri Lactobacillus lactis pada media dasar pertumbuhan alternative dan media dasar penepungan pada bakteri. Bakteri asam laktat tersebut dilakukan peremajaan dan perbanyakan kultur sebanyak $5 \mu$ diinokulasikan ke dalam $5 \mathrm{~mL}$ media MRSB. Media formulasi yang digunakan untuk pertumbuhan bakteri seperti whey tahu + sukrosa $5 \%+$ urea $1 \%$. Media alternative tersebut diinkubasi selama 24 jam. Pengamatan pertumbuhan bakteri dilakukan pada jam ke 0, 4, 8 dan 16 jam dengan metode TPC (Total Plate count). Berbagai media Penepungan bakteri Lactobacillus lactis ditumbuhkan pada media MRSB dan dikeringkan dengan freeze dry selama 48 jam dan dilakukan pengujian viabilitas bakteri Lactobacillus lactis. Media dasar pertumbuhan yang dapat digunakan adalah bakteri Lactobacillus lactis yaitu media whey tahu + sukrosa 5\% + urea $1 \%$ serta hasil viabilitas Lactobacillus lactis pada berbagai media penepungan yang ditumbuhkan pada media MRS dan berbagai media alternative menunjukkan bahwa media penepungan dengan komposisi $100 \%$ tepung karagenan mampu mempertahankan vibilitas sel Lactobacillus lactis.
\end{abstract}

\section{PENDAHULUAN}

Masa simpan dalam suatu bahan pangan memiliki batas dalam masa penyimpananya, kebutuhan bahan pangan sangat penting bagi manusia dimana untuk menunjang kebutuhan hidup. Terbatasnya waktu masa simpan dalam suatu bahan pangan dibutuhkan suatu bahan pengawet alami agar bahan pangan yang digunakan tersebut tidak mudah mengalami kerusakan dan memiliki masa simpan yang lebih lama (Seveline, 2017).

Masa simpan yang lebih lama akan sangat membantu untuk manusia dalam memenuhi kebutuhan pangan. Salah satu alternative yang dapat digunakan untuk mempertahankan kesegaran dan daya tahan secara aman dalam pangan adalah secara biologis dengan penggunaan preserfasi (pengawetan alami) dengan menggunakan bakteriosin yang dapat disintesis oleh bakteri asam laktat (BAL) yang dapat mempertahankan viabilitasnya (Usmiati, 2009).

Penggunaan bakteri asalam laktat menarik perhatian karena potensial untuk diaplikasikan dalam pengawetan produk pangan, yaitu dengan mengontrol bakteri pembusuk dan patogen secara alami. Dengan menggunakan bakteri asam laktat maka waktu dalam masa penyimpanan produk pangan dapat diperpanjang sehingga keamanan pangan dapat meningkat. Pengawetan bahan pangan secara alami digunakan bakteri asam laktat karena tidak berbahaya (Isnawati et al., 2015).

Bakteri asam laktat merupakan bakteri yang memiliki peranan penting sebagai probiotik yang dapat menghambat pertumbuhan bakteribakteri patogen. Bakteri asam laktat mampu memproduksi berbagai senyawa yang dapat menghambat pertumbuhan bakteri patogen seperti asam laktat, hidrogen peroksida ( $\mathrm{H} 2 \mathrm{O} 2)$, karbon dioksida, diacetil, dan bakteriosin Mekanisme penghambatan pertumbuhan bakteri patogen oleh BAL adalah melalui penurunan $\mathrm{pH}$ yang disebabkan sekresi senyawa asam organic (Manguntungi et al., 2020). Bakteri asam laktat (BAL) merupakan bakteri yang memiliki peran utama dalam proses fermentasi. Dalam proses fermentasi digunakan dengan tujuan untuk meningkatkan laju fermentasi sehingga proses fermentasi menjadi lebih singkat, mengontrol proses 
fermentasi, dan mengurangi ketidakseragaman kualitas produk (Hafsan, 2014).

Senyawa asam laktat yang dihasilkan oleh BAL memiliki kemampuan antimikroba karena mampu menggangu kerja membran sel, menghambat transpor aktif, mengurangi $\mathrm{pH}$ intraseluler dan menghambat berbagai fungsi metabolism (Manguntungi et al., 2020).

Bakteri ini akan memulai proses pengasaman secara cepat pada bahan baku dengan memproduksi asam organik, terutama asam laktat. Selain itu, bakteri ini juga memproduksi asam asetat, etanol, komponen aromatik, bakteriosin, eksopolisakarida, dan beberapa enzim penting, sehingga bakteri ini mampu mengendalikan pertumbuhan bakteri patogen dan bakteri pembusuk. Faktor penting dalam pengembangan adalah pemilihan media pertumbuhan bakteri asam laktat.

Media pengembangan starter harus mengandung nutrisi yang sesuai kebutuhan bakteri dan harus memiliki kesamaan dengan media produksi sehingga dapat meminimalkan waktu adaptasi dari kultur starter, mengurangi fase lag dan waktu fermentasi (Muthia et al., 2017). Bakteri Asam Laktat biasanya ditumbuhkan di dalam media de Mann Rogose and Sharpe (MRS), yakni media spesifik untuk pertumbuhan bakteri asam laktat, namun pada skala industri tidak efektif untuk digunakan dikarenakan harga yang relative lebih tinggi, untuk itu dicari media pengganti yang harganya relatif murah namun mengandung sejumlah nutrisi penting yang dapat menunjang pertumbuhan kultur starter bakteri asam laktat (BAL) (Lech, 2020).

Dalam penelitian ini menggunakan bakteri Lactobacillus lactis. Salah satu media alternatif pengganti yang dapat digunakan adalah whey tahu (WT). Whey tahu merupakan limbah organik yang berasal dari industri tahu yang belum layak dibuang ke lingkungan. Jika whey tahu tersebut dibuang langsung tanpa proses pengolahan maka akan terjadi pengendapan zat-zat organik pada badan perairan, proses pembusukan dan berkembangnya mikroorganisme pathogen (Yeni et al., 2016). WT mengandung senyawa-senyawa organik, seperti $\mathrm{N}$ organik $(7,61 \%)$, gula total $(0,32 \%)$, gula reduksi $(0,09 \%)$ dan mineral. Komponen nutrisi yang lengkap dari WT terutama kandungan proteinnya diharapkan sesuai sebagai sumber $\mathrm{N}$ dan mineral untuk media starter BAL (Kurniasari et al., 2011).

Penyimpanan bahan pangan agar memilki masa simpan yang lama salah satu alternativnya dengan menggunakan bakteri asam laktat dengan cara melakukan penepungan atau pengeringan. Pengeringan bertujuan untuk memperpanjang daya simpan, mempermudah distribusi dan memudahkan pemeliharaan.Pembuatan sediaan serbuk bakteri ini dapat dilakukan dengan metode beku (freeze dryer) (pengeringan beku) dapat digunakan (Puspawati et al., 2017). Penelitian ini bertujuan untuk mengetahui viabilitas bakteri Lactobacillus lactis pada media dasar pertumbuhan alternative dan media dasar penepungan pada bakteri.

\section{MATODE PENELITIAN}

\section{Bahan dan Metode \\ Bahan Penelitian}

Bahan yang digunakan meliput Isolat bakteri Lactobacillus lactis, media de Mann Rogose and Sharpe (MRS), whey tahu ,Glukosa, Urea dan Amonium sulfat, Fenol 5\%, Asam Sulfat, Gliserol, $\mathrm{NaCl}, \mathrm{NaOH}$, indikator phenolptalein, tepung beras, tepung karagenan, tepung maizena, tepung tapioka.

\section{Peremajaan dan Perbanyakan Kultur}

Kultur stok bakteri sebanyak $5 \mu$ l diinokulasikan ke dalam $5 \mathrm{~mL}$ media MRSB dan diinkubasi pada suhu $37^{\circ} \mathrm{C}$ selama 24 jam.

\section{Formulasi Media untuk Pertumbuhan Bakteri}

Formulasi media ditentukan berdasarkan persyaratan substrat yang memiliki $\mathrm{C} / \mathrm{N}$ rasio yang sesuai untuk pertumbuhan bakteri. Berdasarkan penelitian Yeni (2016) sumber karbon yang paling baik untuk pertumbuhan bakteri asam laktat dalah media (whey tahu) WT $+5 \%$ glukosa (rasio $\mathrm{C} / \mathrm{N}$ 7,4 ). percobaan dilakukan dengan menggunakan 4 perlakuan media dasar pertumbuhan alternatif yang ditunjukkan pada Tabel 1 .

Tabel 1. Berbagai formulasi media dasar pertumbuhan alternatif

\begin{tabular}{cc}
\hline Jenis Media & Media \\
\hline 1 & MRS \\
2 & Whey Tahu + Sukrosa 5\% + Amonium Sulfat $1 \%$ \\
4 & Whey Tahu + Sukrosa 5\% + Urea $1 \%$ \\
& Whey Tahu \\
\hline
\end{tabular}


Seluruh media diatur tingkat keasamannya pada $\mathrm{pH}$ 6. $1 \%$ bakteri Lactobacillus lactis diinokulasi, kemudian diinkubasi pada suhu $37{ }^{\circ} \mathrm{C}$ selama 24 jam. Pertumbuhan bakteri Lactobacillus lactis diamati pada jam ke 0, 4, 8 dan 16 jam dengan metode TPC (total plate count). Parameter utama yang digunakan untuk menentukan perlakuan terbaik adalah perlakuan media yang memberikan jumlah bakteri Lactobacillus lactis dan total asam tertinggi.

\section{Penepungan Bakteri Lactobacillus lactis}

Sebanyak $5 \mathrm{~mL}$ Isolat bakteri Lactobacillus lactis ditumbuhkan pada $1 \mathrm{~L}$ media MRSB. Diinkubasi pada suhu $37{ }^{\circ} \mathrm{C}$ selama $18-20$ jam. Setelah inkubasi, ditambahkan tepung sesuai dengan tiap perlakuan (Tabel 2). Setelah dicampur hingga merata, kemudian dikeringkan dengan Freeze dryer pada suhu $-55^{\circ} \mathrm{C}$ selama 48 jam hingga kering.

Tabel 2. Media penepungan

\begin{tabular}{cc}
\hline Jenis Perlakuan & Media Penepungan \\
\hline TB & $100 \%$ tepung beras \\
TC & $100 \%$ tepung karagenan \\
TM & $100 \%$ tepung maizena \\
TT & $100 \%$ tepung terigu \\
Campuran & $25 \%$ tepung beras $+25 \%$ tepung karagenan $+25 \%$ tepung maizena + \\
\end{tabular}

\section{Uji Viabilitas Bakteri Lactobacillus lactis}

Sebanyak 1 gr sampel penepungan pada tiap perlakuan di inokulasi dalam $5 \mathrm{~mL}$ media alternatif (Tabel 1) cair. Kemudian diinkubasi pada suhu $37{ }^{\circ} \mathrm{C}$ selama $18-20$ jam. Setelah inkubasi dilakuakan pembuatan seri pengenceran $10^{-1}$ sampai $10^{-7}$. Sebar masing-masing sampel (pengenceran $10^{-}$ ${ }^{1}$ sampai $10^{-7}$ )pada media MRS padat menggunakan metode spread. Diinkubasi pada suhu $37^{\circ} \mathrm{C}$ selama 18-20 jam. Dilakuakan perhitungan jumlah BAL menggunakan metode TPC (Total Plate Count).

\section{HASIL DAN PEMBAHASAN}

\section{Formulasi Media Dasar Pertumbuhan Alternatif}

Hasil jumlah pertumbuhan sel bakteri Lactobacillus lactis pada berbagai formulasi media dasar pertumbuhan alternatif ditunjukkan pada Tabel 3. Jumlah sel bakteri Lactobacillus lactis pada media MRS terus meningkat seiring dengan bertambahnya waktu inkubasi, pada inkubasi jam ke-16 jumlah sel bakteri Lactobacillus lactis yaitu $21,1 \mathrm{CFU} \times 10^{8}$

Tabel 3. Jumlah Sel Bakteri pada Berbagai Waktu Inkubasi dengan Berbagai Formulasi Media Dasar Pertumbuhan Alternatif

\begin{tabular}{cccccc}
\hline \multirow{2}{*}{ No } & \multirow{2}{*}{ Perlakuan Media } & \multicolumn{3}{c}{ CFU (sel/ml) $\mathbf{~ 1 0} \mathbf{8}^{\mathbf{2}}$} \\
\cline { 3 - 6 } & & 0 Jam & 4 Jam & $\mathbf{8 ~ J a m}$ & $\mathbf{1 6}$ Jam \\
\hline $\mathbf{1}$ & MRS & 12,2 & 13,0 & 17,5 & 21,1 \\
$\mathbf{2}$ & Whey Tahu + Sukrosa 5\% + Amonium Sulfat 1\% & 8,7 & 9,4 & 12,9 & 19,0 \\
$\mathbf{3}$ & Whey Tahu + Sukrosa 5\% + Urea 1\% & 7,4 & 17,4 & 18,7 & 19,5 \\
$\mathbf{4}$ & Whey Tahu & 10,6 & 13,9 & 19,1 & 15,3 \\
\hline
\end{tabular}

Media alternatif whey Tahu + Sukrosa 5\% + Amonium Sulfat 1\% menunjukkan pertumbuhan sel bakteri Lactobacillus lactis yang terus meningkat pada tiap waktu inkubasi dengan jumlah sel 19,0 CFU x $10^{8}$ pada waktu inkubasi 16 jam. Media alternatif hey Tahu + Sukrosa 5\% + Urea 1\% juga menunjukkan peningkatan jumlah sel bakteri Lactobacillus lactis pada tiap waktu inkubasi dengan jumlah sel 19,5 CFU x $10^{8}$ pada inkubasi 16 jam. Media whey Tahu juga menunjukkan peningkatan jumlah sel bakteri Lactobacills lactis pada inkubasi jam ke-0 hingga jam ke-8 dengan jumlah sel 19,1 CFU $x \quad 10^{8}$ dan mengalami penurunan jumlah sel pada jam ke-16 dengan jumlah sel 15,3 CFU x $10^{8}$. Jadi media dasar pertumbuhan alternatif yang dapat digunakan untuk pertumbuhan bakteri Lactobacillus lactis yaitu media alternatif whey Tahu + Sukrosa 5\% + Urea $1 \%$.

Hasil analisis komposisi kimia whey tahu menunjukkan bahwa media whey tahu merupakan media yang baik digunakan untuk pertumbuhan bakteri asam laktat karena masih mengandung sejumlah $\mathrm{N}$ yang dapat dimanfaatkan untuk kelangsungan hidup bakteri (Salim, 2008).

Penelitian Champagne et al. (2003), menunjukkan bahwa media whey tahu tanpa suplementasi menghasilkan pertumbuhan bakteri $L$. paracasei ssp. yang lebih rendah dibandingkan dengan whey tahu dengan suplementasi, hal ini 
dikarenakan sedikitnya kandungan gula yang dapat difermentasi oleh bakteri.

Perbedaan jumlah bakteri yang tumbuh pada berbagai media dikarenakan proses fermentasi yang terjadi akibat perbedaan suplementasi yang digunakan.

\section{Media Penepungan}

Viabilitas bakteri Lactobacillus lactis pada berbagai media penepungan dengan media pertumbuhan MRS ditunjukkan pada Tabel 4. Viabilitas Lactobacillus lactis pada media penepungan $100 \%$ TB pada minggu ke I, II dan III menunjukkan tidak ada perbedaan yang nyata dan berbeda nyata terhadap viabilitas pada minggu ke IV dan V. Viabilitas Lactobacillus lactis pada media penepungan $100 \%$ TC pada minggu ke I, II, III, IV dan $\mathrm{V}$ menunjukkan tidak ada perbedaan yang nyata setiap minggunya.

Tabel 4. Viabilitas Bakteri Lactobacillus lactis pada Berbagai Media Penepungan dengan Penggunaan MRS sebagai media Dasar Pertumbuhan

\begin{tabular}{|c|c|c|c|c|c|c|}
\hline \multirow[b]{2}{*}{ No } & \multirow{2}{*}{ Jenis Tepung } & \multicolumn{5}{|c|}{ Minggu ke- [CFU $\left.\left.(\mathrm{sel} / \mathrm{ml}) \times 1^{8}\right)\right]$} \\
\hline & & $\mathbf{I}$ & II & III & IV & $\mathbf{V}$ \\
\hline 1 & $100 \% \mathrm{~TB}$ & $15,5^{\mathrm{a}}$ & $15,5^{\mathrm{a}}$ & $15,3^{\mathrm{a}}$ & $13,8^{b}$ & $13,6^{\mathrm{b}}$ \\
\hline 2 & $100 \% \mathrm{TC}$ & $20,0^{\mathrm{a}}$ & $20,0^{\mathrm{a}}$ & $20,0^{\mathrm{a}}$ & $19,5^{\mathrm{a}}$ & 19,4 \\
\hline 3 & $100 \% \mathrm{TM}$ & $10,3^{\mathrm{a}}$ & $9,5^{\mathrm{b}}$ & $9,3^{\mathrm{b}}$ & $6,3^{c}$ & $5,1^{\mathrm{d}}$ \\
\hline 4 & $100 \% \mathrm{TT}$ & $12,3^{\mathrm{a}}$ & $9,4^{\mathrm{b}}$ & $8,0^{\mathrm{c}}$ & $6,3^{\mathrm{d}}$ & $2,3^{\mathrm{e}}$ \\
\hline 5 & $\begin{aligned} & 25 \% \mathrm{~TB}+25 \% \mathrm{TC}+25 \% \mathrm{TM} \\
&+25 \% \mathrm{TT} \\
&\end{aligned}$ & $14,3^{\mathrm{a}}$ & $14,2^{\mathrm{a}}$ & $14,0^{\mathrm{a}}$ & $13,9^{\mathrm{a}}$ & $11,0^{\mathrm{h}}$ \\
\hline
\end{tabular}

Viabilitas Lactobacillus lactis pada media penepungan $100 \%$ TM pada minggu ke I berbeda nyata terhdap viabilitas minggu ke II dan III, serta berbeda sangat nyata terhadap viabilitas minggu ke IV dan V. Viabilitas Lactobacillus lactis pada media penepungan $100 \%$ TT pada minggu ke I berbeda nyata terhadap viabilitas minggu ke II dan berbeda sangat nyata terhadap viabilitas minggu ke III, IV dan V. Viabilitas Lactobacillus lactis pada media penepungan $25 \% \mathrm{~TB}+25 \% \mathrm{TC}+25 \% \mathrm{TM}+25 \%$ TT pada minggu ke I, II, III dan IV tidak berbeda nyata dan berbeda nyata terhadap viabilitas minggu ke V. Jadi media penepungan yang mampumenjaga viabilitas Lactobacillus lactis pada media MRS yaitu media dengan $100 \%$ tepung karagenan.

Viabilitas Bakteri Lactobacillus lactis pada berbagai media penepungan dengan media pertumbuhan whey tahu + sukrosa $5 \%+$ amonium sulfat $1 \%$ ditunjukkan pada Tabel 5. Viabilitas Lactobacillus lactis pada media penepungan $100 \%$ TB pada minggu ke I berbeda nyata terhadap viabilitas pada minggu ke II dan III serta berbeda sangat nyata terhadap viabilitas minggu ke IV dan V.

Tabel 5. Viabilitas Bakteri Lactobacillus lactis pada Berbagai Media Penepungan dengan Penggunaan Whey Tahu + Sukrosa 5\% + Amonium Sulfat 1\% sebagai media Dasar Penepungan

\begin{tabular}{ccccccc}
\hline \multirow{2}{*}{ No } & \multirow{2}{*}{ Jenis Tepung } & \multicolumn{5}{c}{ Minggu ke- $[$ CFU $(\mathbf{s e l} / \mathbf{m l}) \mathbf{x ~ 1 0}$ ) $]$} \\
\cline { 3 - 6 } & & I & II & III & IV & V \\
\hline 1 & $100 \%$ TB & $19,8^{\mathrm{a}}$ & $17,0^{\mathrm{b}}$ & $17,0^{\mathrm{b}}$ & $16,2^{\mathrm{bc}}$ & $13,0^{\mathrm{c}}$ \\
2 & $100 \% \mathrm{TC}$ & $20,0^{\mathrm{a}}$ & $20,0^{\mathrm{a}}$ & $20,0^{\mathrm{a}}$ & $19,8^{\mathrm{a}}$ & $19,8^{\mathrm{a}}$ \\
3 & $100 \% \mathrm{TM}$ & $11,2^{\mathrm{a}}$ & $11,0^{\mathrm{a}}$ & $9,8^{\mathrm{b}}$ & $6,3^{\mathrm{c}}$ & $3,2^{\mathrm{d}}$ \\
4 & $100 \% \mathrm{TT}$ & $13,0^{\mathrm{a}}$ & $9,7^{\mathrm{b}}$ & $9,3^{\mathrm{b}}$ & $7,2^{\mathrm{c}}$ & $3,6^{\mathrm{d}}$ \\
5 & $25 \% \mathrm{~TB}+25 \% \mathrm{TC}+25 \% \mathrm{TM}$ & $20,0^{\mathrm{a}}$ & $19,4^{\mathrm{a}}$ & $17,8^{\mathrm{b}}$ & $16,7^{\mathrm{a}}$ & $13,0^{\mathrm{d}}$
\end{tabular}

Viabilitas Lactobacillus lactis pada media penepungan $100 \%$ TC pada minggu ke I, II, III, IV dan $\mathrm{V}$ menunjukkan tidak ada perbedaan yang nyata setiap minggunya. Viabilitas Lactobacillus lactis pada media penepungan $100 \%$ TM pada minggu ke I dan II berbeda nyata terhdap viabilitas minggu ke III dan berbeda sangat nyata terhadap viabilitas minggu ke IV dan V. Viabilitas Lactobacillus lactis pada media penepungan $100 \%$ TT pada minggu ke I berbeda nyata terhadap viabilitas minggu ke II dan
III serta berbeda sangat nyata terhadap viabilitas minggu ke IV dan V. Viabilitas Lactobacillus lactis pada media penepungan $25 \% \mathrm{~TB}+25 \% \mathrm{TC}+25 \%$ $\mathrm{TM}+25 \%$ TT pada minggu ke I II dan IV tidak berbeda nyata dan berbeda nyata terhadap viabilitas minggu ke III, serta berbeda sangat nyata terhadap viabilitas minggu ke $\mathrm{V}$. Jadi media penepungan yang mampu menjaga viabilitas Lactobacillus lactis pada media whey tahu + sukrosa $5 \%+$ amonium 
sulfat $1 \%$ yaitu media dengan $100 \%$ tepung karagenan.

Hasil viabilitas bakteri Lactobacillus lactis pada berbagai media penepungan dengan media pertumbuhan whey tahu + sukrosa 5\% + urea $1 \%$ ditunjukan pada Tabel 6 .

Tabel 6. Viabilitas Bakteri Lactobacillus lactis pada Berbagai Media Penepungan dengan Penggunaan Whey Tahu + Sukrosa 5\% + Urea 1\% sebagai media Dasar Penepungan

\begin{tabular}{|c|c|c|c|c|c|c|}
\hline \multirow{2}{*}{ No } & \multirow{2}{*}{ Jenis Tepung } & \multicolumn{5}{|c|}{ Minggu ke- [CFU (sel/ml) x 10 $\left.\left.{ }^{8}\right)\right]$} \\
\hline & & $\mathbf{I}$ & II & III & IV & $\mathbf{V}$ \\
\hline 1 & $100 \% \mathrm{~TB}$ & $19,4^{\mathrm{a}}$ & $18,9^{\mathrm{a}}$ & $18,3^{\mathrm{bc}}$ & $18,2^{\mathrm{bc}}$ & $14,4^{\mathrm{d}}$ \\
\hline 2 & $100 \% \mathrm{TC}$ & $23,0^{\mathrm{a}}$ & $23,0^{\mathrm{a}}$ & $23,0^{\mathrm{a}}$ & $22,8^{a}$ & $22,5^{\mathrm{a}}$ \\
\hline 3 & $100 \% \mathrm{TM}$ & $17,5^{\mathrm{a}}$ & $16,0^{\mathrm{b}}$ & $11,3^{\mathrm{c}}$ & $10,0^{\mathrm{d}}$ & $7,5^{\mathrm{e}}$ \\
\hline 4 & $100 \% \mathrm{TT}$ & $17,0^{\mathrm{a}}$ & $15,0^{\mathrm{b}}$ & $12,3^{\mathrm{c}}$ & $7,5^{\mathrm{d}}$ & $3,0^{\mathrm{e}}$ \\
\hline 5 & $\begin{aligned} 25 \% \mathrm{~TB} & +25 \% \mathrm{TC}+25 \% \mathrm{TM} \\
& +25 \% \mathrm{TT}\end{aligned}$ & $16,5^{\mathrm{a}}$ & $16,5^{\mathrm{a}}$ & $13,0^{\mathrm{b}}$ & $13,0^{\mathrm{b}}$ & $13,2^{\mathrm{c}}$ \\
\hline
\end{tabular}

Viabilitas Lactobacillus lactis pada media penepungan $100 \%$ TB pada minggu ke I dan II berbeda sangat nyata terhadap viabilitas pada minggu ke III, IV dan V. Viabilitas Lactobacillus lactis pada media penepungan $100 \%$ TC pada minggu ke I, II, III, IV dan V menunjukkan tidak ada perbedaan yang nyata setiap minggunya. Viabilitas Lactobacillus lactis pada media penepungan $100 \%$ TM pada minggu ke I berbeda nyata terhdap viabilitas minggu ke II dan berbeda sangat nyata terhadap viabilitas minggu ke III, IV dan V. Viabilitas Lactobacillus lactis pada media penepungan $100 \%$ TT pada minggu ke I berbeda nyata terhadap viabilitas minggu ke II dan berbeda sangat nyata terhadap viabilitas minggu ke III, IV dan V. Viabilitas Lactobacillus lactis pada media penepungan $25 \% \mathrm{~TB}+25 \% \mathrm{TC}+25 \% \mathrm{TM}+25 \%$
TT pada minggu ke I dan II tidak berbeda nyata dan berbeda nyata terhadap viabilitas minggu ke III dan IV, serta berbeda sangat nyata terhadap viabilitas minggu ke V. Jadi media penepungan yang mampu menjaga viabilitas Lactobacillus lactis pada media whey tahu + sukrosa $5 \%$ + urea $1 \%$ yaitu media dengan $100 \%$ tepung karagenan.

Hasil viabilitas bakteri Lactobacillus lactis pada berbagai media penepungan dengan media pertumbuhan whey tahu ditunjukkan pada Tabel 7 . Viabilitas Lactobacillus lactis pada media penepungan $100 \%$ TB pada minggu ke I dan II berbeda nyata terhadap viabilitas pada minggu ke III, IV dan V. Viabilitas Lactobacillus lactis pada media penepungan $100 \%$ TC pada minggu ke I, II, III, IV dan V menunjukkan tidak ada perbedaan yang nyata setiap minggunya.

Tabel 7. Viabilitas Bakteri Lactobacillus lactis pada Berbagai Media Penepungan dengan Penggunaan Whey Tahu sebagai media Dasar Penepungan

\begin{tabular}{|c|c|c|c|c|c|c|}
\hline \multirow{2}{*}{ No } & \multirow{2}{*}{ Jenis Tepung } & \multicolumn{5}{|c|}{ Minggu ke- [CFU (sel/ml) x 10 $\left.\left.{ }^{8}\right)\right]$} \\
\hline & & $\mathbf{I}$ & II & III & IV & $\mathbf{V}$ \\
\hline 1 & $100 \% \mathrm{~TB}$ & $15,8^{\mathrm{a}}$ & $15,0^{\mathrm{a}}$ & $13,2^{\mathrm{b}}$ & $13,2^{\mathrm{b}}$ & $12,9^{b}$ \\
\hline 2 & $100 \% \mathrm{TC}$ & $16,6^{\mathrm{a}}$ & $16,6^{\mathrm{a}}$ & $216,3^{\mathrm{a}}$ & $16,3^{\mathrm{a}}$ & $16,2^{\mathrm{a}}$ \\
\hline 3 & $100 \% \mathrm{TM}$ & $15,9^{\mathrm{a}}$ & $12,0^{\mathrm{b}}$ & $7,8^{\mathrm{c}}$ & $7,2^{\mathrm{c}}$ & $3,4^{\mathrm{d}}$ \\
\hline 4 & $100 \% \mathrm{TT}$ & $15,7^{\mathrm{a}}$ & $12,3^{\mathrm{b}}$ & $8,5^{\mathrm{c}}$ & $4,3^{\mathrm{d}}$ & $2,1^{\mathrm{e}}$ \\
\hline 5 & $\begin{aligned} 25 \% \mathrm{~TB}+ & 25 \% \mathrm{TC}+25 \% \mathrm{TM} \\
& +25 \% \mathrm{TT}\end{aligned}$ & $16,5^{\mathrm{a}}$ & $16,4^{\mathrm{a}}$ & $16,4^{\mathrm{a}}$ & $14,5^{\mathrm{b}}$ & $13,9^{b}$ \\
\hline
\end{tabular}

Viabilitas Lactobacillus lactis pada media penepungan $100 \%$ TM pada minggu ke I berbeda nyata terhdap viabilitas minggu ke II dan berbeda sangat nyata terhadap viabilitas minggu ke III, IV dan V. Viabilitas Lactobacillus lactis pada media penepungan $100 \%$ TT pada minggu ke I berbeda nyata terhadap viabilitas minggu ke II dan berbeda sangat nyata terhadap viabilitas minggu ke III, IV dan V. Viabilitas Lactobacillus lactis pada media penepungan $25 \% \mathrm{~TB}+25 \% \mathrm{TC}+25 \% \mathrm{TM}+25 \%$ TT pada minggu ke I, II dan II berbeda nyata terhadap viabilitas minggu ke III,IV dan V. Jadi media penepungan yang mampu menjaga viabilitas Lactobacillus lactis pada media whey tahu yaitu media dengan $100 \%$ tepung karagenan.

Berdasarkan hasil viabilitas Lactobacillus lactis pada beberapa media penepungan yang ditumbuhkan pada media MRS dan beberapa jenis media alternatif, menunjukkan bahwa media penepungan dengan komposisi $100 \%$ tepung karagenan mampu mempertahankan viabilitas sel Lactobacillus lactis selama 5 minggu. Berdasarkan 
hasil beberapa penelitian, karagenan digunakan sebagai bahan enkapsulasi (Burgain et al., 2011; Peres et al., 2012; Sarao dan Arora, 2017). Karaginan merupakan polisakarida alami yang mengandung struktur pengikat silang oleh $D$ galactose-4-sulfate dan 3,6-dehydrated-Dgalactose yang digunakan sebagai zat aditif makanan dan karena sifat gelasinya, karaginan dapat digunakan sebagai bahan enkapsulasi (Shi et al., 2013). Karagenan sebagai bahan enkapsulasi mampu melindungi sel bakteri dari kondisi lingkungan yang tidak menguntungkan (Ulfah, 2013).

Hasi penelitian Shi et al. (2013), menunjukkan bahwa bakteri Lactobacillus bulgaricus yag telah dienkapsulasi dengan karagenan mampu bertahan pada kondisi lingkungan yang merugikan di dalam saluran pencernaan, mampu mempertahankan viabiitas sel selama dua jam dalam cairan lambung dengan $\mathrm{pH}$ 2,0 - 2,5 serta mempertahankan viabilitas sel selama satu bulan dalam penyimpanan suhu $4^{\circ} \mathrm{C}$. Doleyres et al. (2002) Melaporkan bahwa sel probiotik yang dienkapsulasi dengan karagenan mampu meningkatkan ketahanan sel terhadap tekanan, seperti pengeringan beku, hidrogen peroksida dan kondisi gastrointestinal.

Penelitian Pangestu et al. (2017), juga menunjukkan hasil bahwa enkapsulasi dengan karagenan mampu mempertahankan senyawa antioksidan dan viabilitas sel bakteri asam laktat tanpa mempengaruhi nilai $\mathrm{pH}$ pada yogurt powder, karena karagenan memiliki sifat pseudoplastik yang dapat bertindak sebagai mikroenkapsulan dan meningkatkan gaya adhesi antara dinding dan bahan inti sehingga dapat melindungi senyawa antioksidan saat proses thermal.

\section{PENUTUP}

\section{Kesimpulan}

Media dasar pertumbuhan alternative dari 4 jenis media yang digunakan menunjukkan bahwa media dasar pertumbuhan yang dapat digunakan adalah bakteri Lactobacillus lactis yaitu media whey tahu + sukrosa $5 \%$ + urea $1 \%$ pada waktu inkubasi selama 16 jam serta hasil viabilitas Lactobacillus lactis pada berbagai media penepungan yang ditumbuhkan pada media MRS dan berbagai media alternative menunjukkan bahwa media penepungan dengan komposisi $100 \%$ tepung karagenan mampu mempertahankan vibilitas sel Lactobacillus lactis selama 5 minggu.

\section{REFERENSI}

Burgain J, Gaiani C, Linder M, dan Scher J. 2011. Encapsulation of probiotic living cells: From laboratory scale to industrial applications. Journal of food engineering. 104(4): 467-483.

Champagne CP, Lee BH, dan Goulet J. 2003. Growth of Lactobacillus paracasei ssp. paracasei on tofu whey. International journal offood microbiology. 89(1): 6775 .

Doleyres Y, Fliss I, dan Lacroix C. 2002. Quantitative determination of the spatial distribution of pure-and mixedstrain immobilized cells in gel beads by immunofluorescence. Applied microbiology and biotechnology. 59(23): 297-302.

Hafsan. 2014. Bakteriosin asal bakteri asam laktat sebagai biopreservatif pangan. $J$ Teknosains. 2 (8):175-184.

Ismawati N, Agustina LNA, dan Linda S. 2015. Whey Tahu Sebagai Penghasil Bioelektrisitas Pada System Microbial Fuel Cell Dengan Lactobacillus plantarum. Jurnal Sains Dan Matematika. 23(2):43-49

Kurniasari N, Sida A, Endang SR, dan Tyas U. 2011. The growth of Pediococcus acidilactic F-11 in Tofu Whey. Proceeding the 3rd International Conference of Indonesian Society for Lactic Acid Bacteria: Better Life with Lactic Acid Bacteria: Exploring Novel Function of Lactic Acid Baceria. ISBN: 978-979- 19546. 1-7.

Lech Magdalena. 2020. Optimisation Of ProteinFree Waste Whey Supplementation Used For The Industrial Microbiological Production Of Lactic Acid. Biochemical Engineering Journal.1-3

Manguntungi B, Sari AP, Chaidir RRA, Islam I, Vanggy LR, Sufiyanti N, ... dan Kusuma WD. 2020. Isolasi, Karakterisasi, dan Aktivitas Antibakteri BAL Indigenous dari Sarang Lebah Trigona spp. Asal Kabupaten Sumbawa. Biotropika: Journal of Tropical Biology. 8(1): 1318. 
Manguntungi B, Sari AP, Ariandi Chaidir RRA, Islam I, Suharli L, Vanggy LR, Sufiyanti N, ... dan Kusuma WD. 2020. ISOLASI DAN KARAKTERISASI BAKTERI ASAM LAKTAT DARI MADU HITAM SUMBAWA DAN POTENSINYA SEBAGAI SENYAWA ANTIMIKROBA. Jurnal Pendidikan Biologi undiksha. 7(1): 1-7.

Muthia, Kunti, Nadiyatan S. a, Purbowatiningrum Ria Sarjono a, Agustina L. N. Aminin. 2017. Aktivitas Antioksidan dan Antibakteri Produk Fermentasi Susu Kedelai dan Whey Tahu menggunakan Bakteri Asam Laktat Komersial. Jurnal kimia sains dan aplikasi. 20(1): 9-11

Pangestu RF, Legowo AM, Al-Baarri ANM, dan Pramono YB. 2017. Aktivitas antioksidan, $\mathrm{pH}$, viskositas, viabilitas bakteri asam laktat (BAL) pada yogurt powder daun kopi dengan jumlah karagenan yang berbeda. Jurnal Aplikasi Teknologi Pangan. $6(2)$.

Peres CM, Peres C, Hernández-Mendoza A, dan Malcata FX. 2012. Review on fermented plant materials as carriers and sources of potentially probiotic lactic acid bacteria-with an emphasis on table olives. Trends in Food Science \& Technology. 26(1): 31-42.

Puspawati, Ni Nyoman, Lilies Nuraida, Dede Robiatul Adawiyah. 2010.

Penggunaan Berbagai Jenis Bahan Pelindung Untuk Mempertahankan Viabilitas Bakteri Asam Laktat Yang Diisolasi Dari Air Susu Ibu Pada Proses Pengeringan Beku. Jurnal Teknologi Industry Dan Hasil Pangan.21 (1): 59-60
Salim, T. 2008. Pemanfaatan Limbah Pisang untuk Pembuatan Kompos Menggunakan Komposter Rotary Drum. Dalam Prosiding Seminar Nasional Teknoin.

Sarao LK, dan Arora M. 2017. Probiotics, prebiotics, and microencapsulation: A review. Critical reviews in food science and nutrition. 57(2):344-371.

Seveline.2017. Kajian Pustaka Teknik Pengeringan Semprot (Spray Drying) Untuk Pengawetan Dan Produksi Probiotik. Jurnal Agroindustri Halal. 3 (1): 8082

Shi LE, Li ZH, Zhang ZL, Zhang TT, Yu WM, Zhou ML, dan Tang ZX. 2013. Encapsulation of Lactobacillus bulgaricus in carrageenan-locust bean gum coated milk microspheres with double layer structure. LWT-Food Science and Technology. 54(1): 147151.

Ulfah M. 2013. Addition of flours from dahlia tuber, soybean and garlic as prebiotic sources for probiotic encapsulation. Jurnal Teknologi dan Industri Pangan. 24(1): 14-21.

Usmiati S, 2009. Penggunaan Bakteriosin sebagai Alternatif Pengawetan DagingAyam (Kasus Daging Ayam Berformalin), Jurnal Teknosains 14(1): 145-15411

Yeni, Anja Meryandini, dan Titi Candra Sunarti. 2016. Penggunaan Substrat Whey Tahu Untuk Produksi Biomassa Oleh Pediococcus pentosaceus E.1222. Jurnal Teknologi Industry Pertanian. 26 (3): 284-285 